\title{
Crapemyrtle Aphid, Sarucallis kahawaluokalani (Kirkaldy) (Insecta: Hemiptera: Aphididae) ${ }^{1}$
}

John Herbert and Russ F. Mizell, $I I^{2}$

\section{Introduction}

The crapemyrtle aphid, Sarucallis

kahawaluokalani (Kirkaldy), is the most important insect pest of crape myrtle Lagerstroemia spp. in the United States. Although native to southeast Asia, crapemyrtle aphid was described by Kirkaldy from specimens collected in Hawaii. In the U.S., crapemyrtle aphids are monophagous; feeding exclusively on crape myrtle and do not attack or damage other plant species. Heavy infestations may cause cosmetic damage that detracts from the visual aesthetics of crape myrtle, but feeding has not been shown to have long term effects on plant health or vigor.

\section{Synonymy}

\section{Synonyms: Tinocallis kahawaluokalani} (Kirkaldy)

\section{Distribution}

Crapemyrtle aphids are distributed throughout the tropics, India, China, Korea, Japan, southeastern United States, Hawaii, and anywhere crape myrtle is grown.

\section{Description}

Insects in the order Hemiptera have incomplete or gradual metamorphosis, where the nymphal or immature stages appear as small adults without wings. Crapemyrtle aphids are minute insects, and identifying characters are best seen with the aid of a stereomicroscope.

Nymphal stages of the crapemyrtle aphid are pale to bright yellow with black spike or hair like projections on their abdomen. Adults are also yellow in color but differ from nymphs in having black spots and two large black tubercles on the dorsal surface of the abdomen. Unlike other aphid species that produce winged forms as a result of environmental or reproductive stimuli, all adult crapemyrtle aphids bear wings that are held roof like over the body and mottled with black markings.

\section{Biology}

The life cycle of the crapemyrtle aphid is holocyclic; meaning it consists of both asexual and sexual reproduction. Eggs hatch in early spring when leaf buds break and all aphids that emerge from these eggs are female (fundatrix). After developing into an

1. This document is EENY-365 (IN663), one of a series of Featured Creatures from the Entomology and Nematology Department, Florida Cooperative Extension Service, Institute of Food and Agricultural Sciences, University of Florida. Published: February, 2006. This document is also available on Featured Creatures Website at http://creatures.ifas.ufl.edu. Please visit the EDIS Website at http://edis.ifas.ufl.edu. 2. John Herbert and Russ F. Mizell, III, Department of Entomology and Nematology, University of Florida, Gainesville, FL.

The Institute of Food and Agricultural Sciences (IFAS) is an Equal Opportunity Institution authorized to provide research, educational information and other services only to individuals and institutions that function with non-discrimination with respect to race, creed, color, religion, age, disability, sex, sexual orientation, marital status, national origin, political opinions or affiliations. U.S. Department of Agriculture, Cooperative Extension Service, University of Florida, IFAS, Florida A. \& M. University Cooperative Extension Program, and Boards of County Commissioners Cooperating. Larry Arrington, Dean 


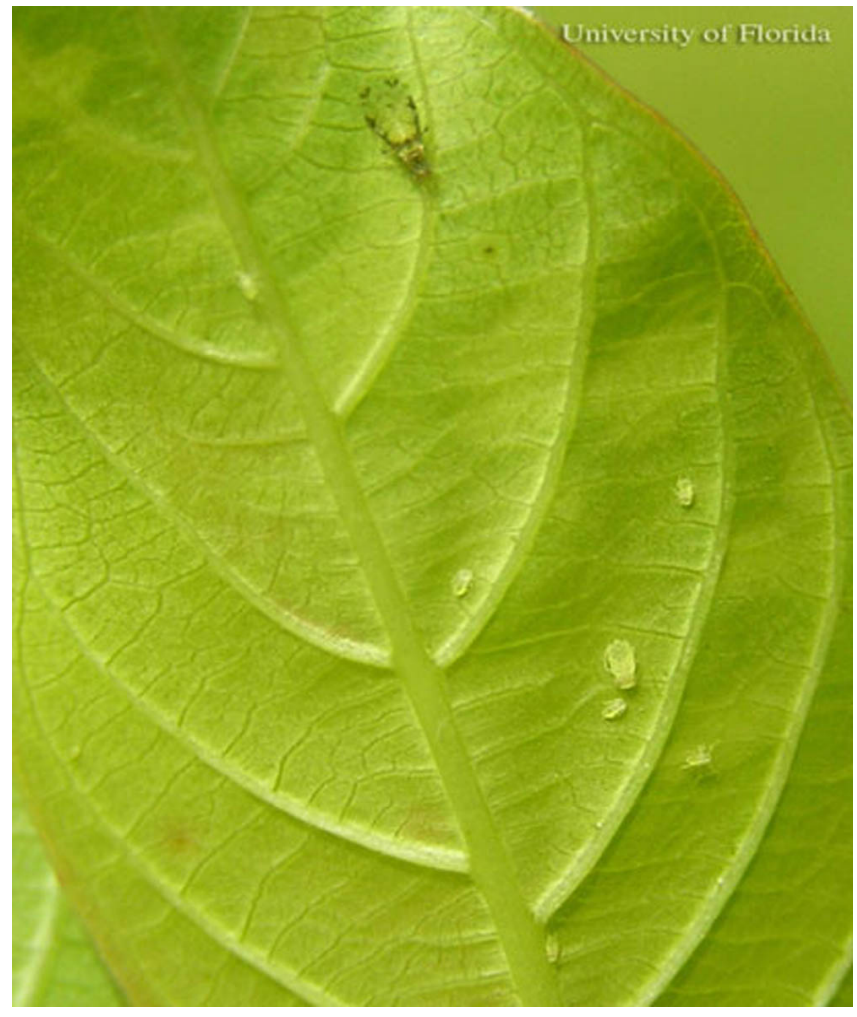

Figure 1. Adult and nymphal crapemyrtle aphids, Sarucallis kahawaluokalani (Kirkaldy), on the adaxial side of the leaf of 'Apalachee' crape myrtle (Lagerstroemia indica $x$ Lagerstroemia faurie). Credits: John Herbert, University of Florida

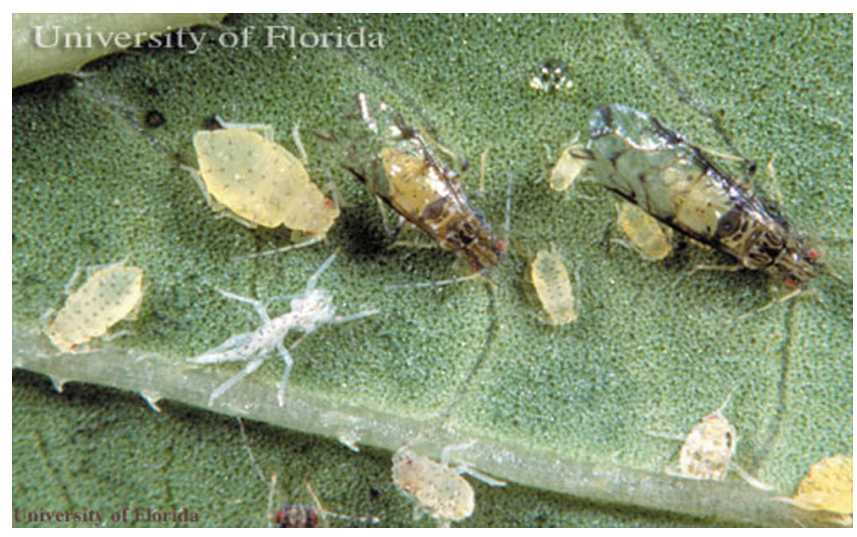

Figure 2. Adults, nymphs and cast skin (exuviae) of the crapemyrtle aphid, Sarucallis kahawaluokalani (Kirkaldy). Credits: University of Florida

adult, the fundatrix reproduces through a form of asexual reproduction known as parthenogenesis and gives live birth to female nymphs (virginoparae). Subsequent generations of aphids are also referred to as virginoparae and produce all female offspring through parthenogenesis during spring and summer.
When photoperiod and temperature decrease in the autumn, virginoparae give birth to a generation of aphids that produce both male and female aphids (sexuparae). Female offspring of sexuparae (oviparae) mate with males and produce eggs. Oviparae produce four to six eggs and place the eggs in crevices located on the bark of crape myrtle stems. Overwintering eggs will hatch the following spring in response to temperature and photoperiod stimuli.

Crapemyrtle aphids have four nymphal stages (instars) before developing into adults. Development time is dependent on ambient temperature, and under optimal conditions, crapemyrtle aphids can develop from first instar nymph to adult in five days. Adults give live birth to first instar nymphs that began developing within their mother when she was a nymph. Therefore, each virginoparae adult is capable of producing offspring upon emergence and can produce six or more offspring within 24 hours of becoming an adult. Adults may live as long as 14 days and produce over 150 offspring in their lifetime. Under optimal conditions, aphid populations grow at astonishing rates due to the high levels of fecundity and low development times. Aphid populations are commonly ignored or escape detection until they have reached damaging levels.

\section{Damage}

Crapemyrtle aphids damage crape myrtle cosmetically and are not known to vector any plant diseases. Damage to crape myrtle is an indirect result of aphid feeding and does not result in permanent damage or long term effects on plant vigor. Crapemyrtle aphids feed on phloem sap in which the primary constituents are sugar and water. The proportion of nutrients to sugar and water within the phloem is extremely low, but aphids have evolved a mechanism that allows them to utilize the trace amounts of nutrients within the phloem.

Amino acids and other essential nutrients are separated with a special filter chamber located in the gut, and excess sugar and water are excreted from the body as small sugary droplets called honeydew. Crapemyrtle aphids eject honeydew away from their feeding location preventing them from becoming entangled within the sticky secretion. Honeydew 


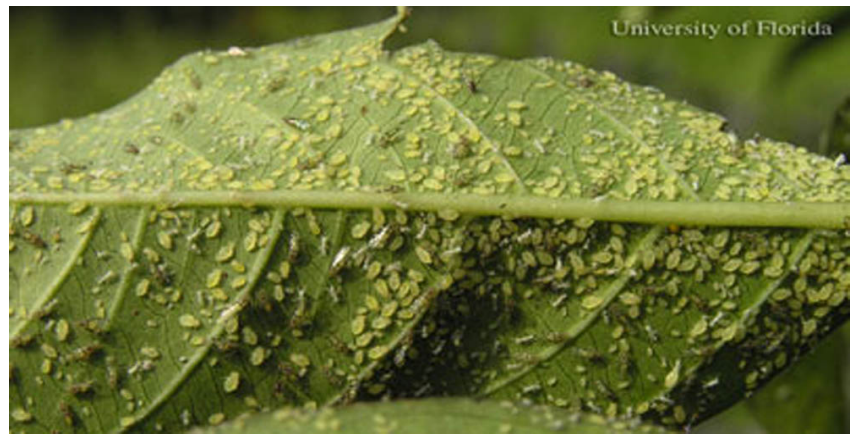

Figure 3. 'Apalachee' crape myrtle (Lagerstroemia indica $x$ Lagerstroemia faurie) with a crapemyrtle aphid, Sarucallis kahawaluokalani (Kirkaldy), infestation that has reached damaging levels. Credits: John Herbert, University of Florida

accumulates on objects below aphid populations and is commonly seen as a shiny coating on the tops of leaves and stems. Molds and other microorganisms can grow on these surfaces utilizing the rich sugary honeydew as a food source.

Black sooty molds are fungi that grow on honeydew produced by aphids or other phloem feeding insects. Capnodium is a genus of fungus that has a species associated exclusively with crapemyrtle aphid honeydew. This fungus species is not yet described and therefore is known only as Capnodium sp. Black sooty mold can turn the entire plant and unsightly black color detracting from the visual aesthetics of crape myrtle. When aphid infestations are severe, thick carpets of black sooty mold interfere with photosynthesis and may cause early leaf drop or complete defoliation of affected plants. However, defoliation is unlikely to affect long term plant health or vigor and plants typically rebound and bloom beautifully in the following years.

\section{Management}

Ladybird beetles (Coccinellidae), green lace wings (Chrysopidae), flower fly larvae (Syrphidae), and generalist insect predators attack crapemyrtle aphids. Larvae and adults of the multicolored Asian Lady beetle, Harmonia axyridis, feed on large quantities of crapemyrtle aphids and provide natural control when aphid numbers are low. However, aphid populations often escape the control of natural enemies near the end of July and early August in Florida.

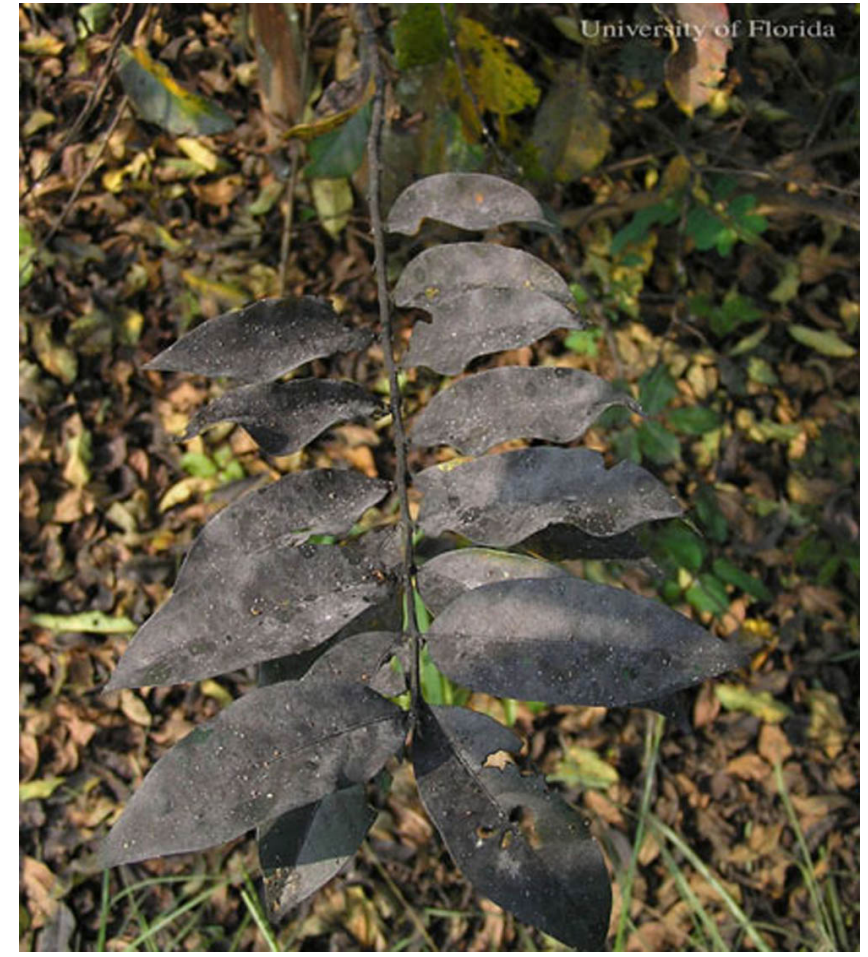

Figure 4. 'Apalachee' crape myrtle (Lagerstroemia indica $x$ Lagerstroemia faurie) covered with black sooty mold as a result of aphid honeydew. Credits: John Herbert, University of Florida

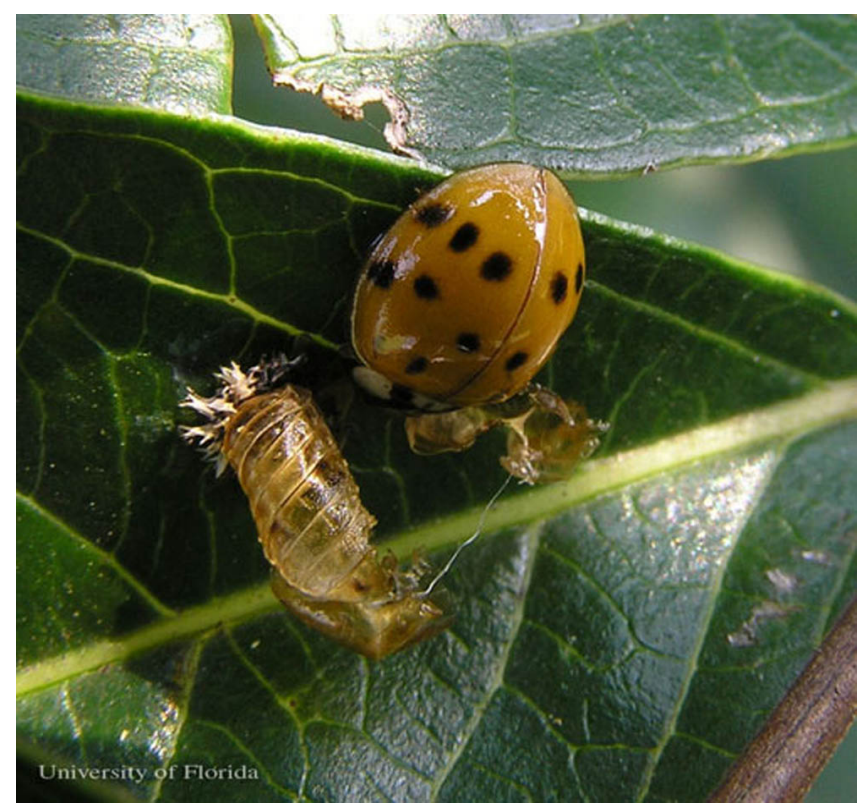

Figure 5. The multicolored Asian lady beetle, Harmonia axyridis, after eclosion (emergence) as an adult. Pupal skin can be seen on the leaf surface. Credits: John Herbert, University of Florida

Alternative control tactics for controlling crapemyrtle aphids are insecticidal soaps or systemic insecticides. Insecticidal soaps can be used to control heavy aphid infestations, but should be used only 
when aphid populations have escaped natural control and as a last resort. If applied with the proper timing and dosage, systemic insecticides may prevent the formation of aphid populations. Insect Management Guide for landscape plants (http://edis.ifas.ufl.edu/IG013).

\section{Ecological Interactions}

Crapemyrtle aphid populations can increase the number of insect natural enemies within the landscape and are a valuable resource for many aphid and generalist predators. For example, green lacewings are important for controlling economically important aphid pests such as pecan aphids. Lacewings can use crapemyrtle aphids as an alternative food source when the number of pecan aphids becomes scarce allowing populations of lacewings to remain high. Pecan aphids typically exhibit resurgence in the fall when crapemyrtle aphid populations begin to diminish and thus, aphid predators can return to pecan orchards offering greater control of pecan aphids. Insect natural enemies that are not aphid predators can also benefit from low to moderate aphid populations.

Predaceous Hymenoptera such as paper wasps (Vespidae), Sphecid wasps (Sphecidae), ants (Formicidae), and parasitoids use honeydew as an adult energy resource. Studies indicate that adult Hymenoptera have increased longevity and foraging efficiency when provided with a source of sugar like honeydew. Contrary to popular belief, wasps can be extremely beneficial in the landscape for controlling insect pests. Paper and Sphecid wasps prey on caterpillars, spiders, and other arthropod pests that are commonly found in backyards and gardens. Ecological interactions are important considerations before deciding on a management practice. Insecticidal sprays and soaps do not generally discriminate between predator and prey, and thus, should only be used when absolutely necessary.

\section{Selected References}

Alverson DR, Allen RK. 1991. Life History of the crapemyrtle aphid. Proceedings of the SNA Research Conference 36:164-167.
Alverson DR, Allen RK. 1992. Bionomics of the crapemyrtle aphid (Homoptera: Aphididae). Journal of Entomological Science 27:445-457.

Alverson DR, Allen RK. 1992. Suitability of Natchez vs. Carolina Beauty Crapemyrtle cultivars as hosts for the crapemyrtle aphid. Proceedings of the SNA Research Conference 37:160-162.

Knox GW. 2003. Crape Myrtle in Florida. EDIS. http://edis.ifas.ufl.edu/MG266 (21 February 2006).

Mizell RF III. Schiffhauer DE. 1987. Seasonal abundance of the crapemyrtle aphid, Sarucallis kahawaluokalani, in relation to the pecan aphids, Monellia caryella and Monelliopsis pecanis and their common predators. Entomophaga 32:511-520.

Mizell RF III. and G. W. Knox. 1993. Susceptibility of crapemyrtle, Lagerstroemia indica L., to the crapemyrtle aphid (Homoptera: Aphididae) in North Florida. Journal of Entomological Science 28:1-7.

Mizell RF III, Bennett FD, Reed. DK 2002. Unsuccessful search for parasites of the crapemyrtle aphid, Tinocallis kahawaluokalani (Homoptera: Aphididae). Florida Entomologist 85:521-523.

Mizell RF III, Knox GW. (2005). Crape Myrtle: Beauty And Biological Control. http://ufinsect.ifas. ufl.edu/crape_myrtle.htm (14 February 2006).

Mizell RF, Fasulo TR, Short DE. (1998). Aphids. Woody Bug. http://woodypest.ifas.ufl.edu/ aphids.htm (15 February 2006). 